\title{
A NEW SPECIES OF PORROGLOSSUM (ORCHIDACEAE, PLEUROTHALLIDINAE) FROM COLOMBIA
}

\author{
MARTA KOLANOWSKA ${ }^{1} \&$ DARIUSz L. SZlachetKo
}

\begin{abstract}
The Neotropical orchid genus Porroglossum Schltr. is one of most poorly recognized genera within Pleurothallidinae, partly due to an insufficiency of herbarium material. An examination of material collected recently in the Colombian department of Putumayo revealed the existence of a new species of Porroglossum which is described, illustrated and placed within a key to identification of Colombian Porroglossum species.
\end{abstract}

Key words: Andes, biodiversity, Neotropics, Putumayo, taxonomy

Marta Kolanowska \& Dariusz L. Szlachetko, Department of Plant Taxonomy and Nature Conservation, University of Gdańsk, ul. Wita Stwosza 59,80-308 Gdańsk, Poland; e-mail: martakolanowska@wp.pl

\section{INTRODUCTION}

The genus Porroglossum Schltr. was proposed in 1920 by Rudolf Schlechter to encompass species characterized by their apical anther and elongated, curved column foot with the free apex previously classified under Masdevallia Ruiz \& Par. The author transferred to the new taxon just two species: P. colombianum Schltr. [currently classified under P. mordax (Rchb. f.) Sweet] and P. muscosum (Rchb. f.) Schltr., but further studies on Pleurothallidinae (Luer 1987) resulted in many additional species transfers from Masdevallia.

Despite the ongoing discussion on the delimitation of genera within Pleurothallidinae (Pridgeon et al. 2001; Luer 2002), the taxonomic separateness of Porroglossum is not in doubt. Plants of the genus are characterized by sepals connate to near the middle, forming a sepaline cup, with apices usually contracted into tails and small cartilaginous petals (Luer 1987). Porroglossum species developed a remarkable pollination system. The lip snaps shut when stimulated by an insect, thereby pushing the pollinator against the column and ensuring that the pollinia will be attached to its body. This lip movement is made possible by the relaxation of its long strap-like claw, thereby

\footnotetext{
1 Corresponding author
}

reflexing the lip backward. Although this reproduction mechanism has been precisely described by scientists (e.g., Bean 1887; Oliver 1888; Luer 1987), no such event has been recorded in nature (Merino et al. 2010).

Currently Porroglossum includes 43 species whose distribution is limited to the Andean region. The geographical range of the genus extends from Colombia and Venezuela to Bolivia and Brazil, with the greatest diversity observed in Ecuador (Pridgeon 2005; Merino et al. 2010; Luer 2011). With 10 species reported so far (Ortiz Valdivieso \& Uribe Vélez 2007), Colombia is considered to have the second-highest concentration of Porroglossum species (Merino et al. 2010).

During the course of study on Orchidaceae occurring in the Colombian department of Putumayo, a distinct Porroglossum species was found. It is described here as new.

\section{DESCRIPTION OF THE NEW SPECIES}

Porroglossum medinae Kolan. \& Szlach., sp. nov. Figs $1 \& 2$

Species similar to Peruvian P. meridionale P. Ortiz and P. peruvianum Sweet, from which it differs by its shortpetiolate leaf, single-flowered inflorescence, oblong 
petals narrowing above the middle into a rounded apex and minutely ciliate in the apical part, cuneate-triangular lip with 3-veined disc, and pyramidal basal callus.

Holotype: COLOMBIA, Putumayo, Valle del Sibundoy. Km 5 new road San Francisco-Mocoa, alt. 2300 m, Coll 5 May 2012, Cult. R. Medina 577 (MEDEL).

Caespitose plants. Ramicaul erect, slender, up to $1 \mathrm{~cm}$ long. Leaf erect, coriaceous, minutely verrucose, short-petiolate; blade $1.8-2.3 \mathrm{~cm}$ long, $0.8-1.0 \mathrm{~cm}$ wide, elliptical, apex obtuse, minutely 3-dentate; petiole up to $0.5 \mathrm{~cm}$ long. Inflorescence single-flowered; peduncle $c a 11 \mathrm{~cm}$ long, slender, glabrous with $\mathrm{ca} 3$ distant tubular sheaths. Floral bract tubular, 4-5 $\mathrm{mm}$ long. Pedicel $3 \mathrm{~mm}$ long. Ovary verrucose, $8-9 \mathrm{~mm}$ long. Flowers resupi-

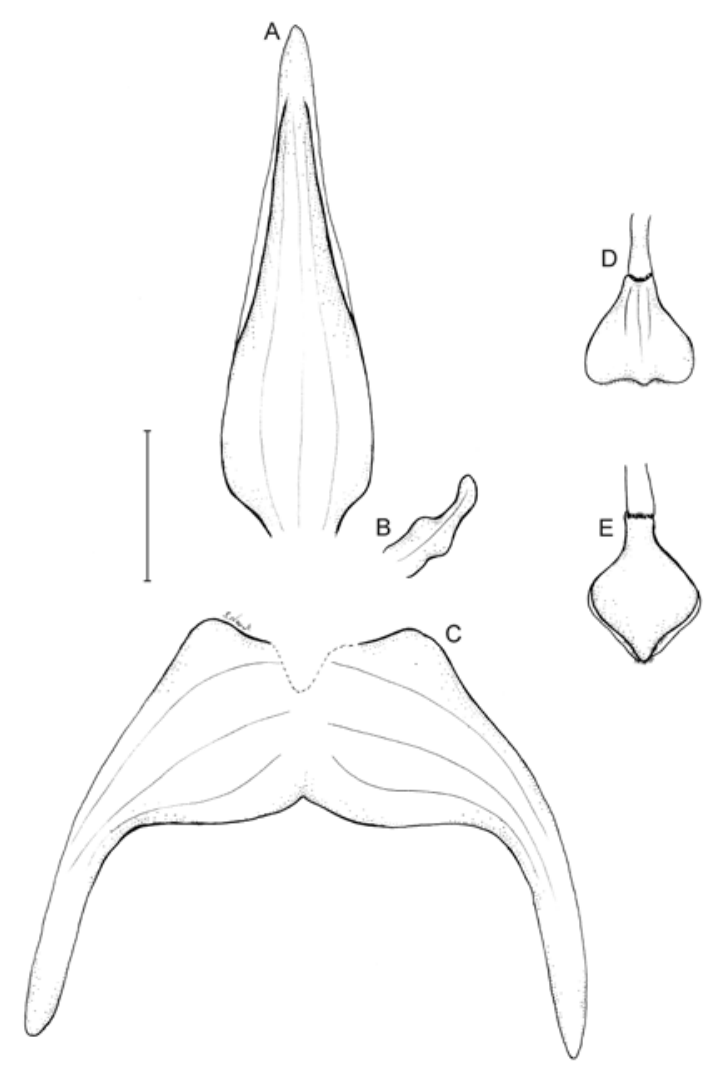

Fig. 1. Porroglossum medinae Kolan. \& Szlach., sp. nov. dissected perianth. A - dorsal sepal, B - petal, C - lateral sepals, D \& E - lip. Drawn by S. Nowak from the holotype. Scale bar $=5 \mathrm{~mm}$. nate, sepals brownish yellow with darker tails, petals yellow, lip white with purple flush in the central part. Sepals glabrous, 3-veined. Dorsal sepal 16-17 mm long in total, ca $5 \mathrm{~mm}$ wide, connate to lateral sepals for $c a 2 \mathrm{~mm}$, ovate-lanceolate, apical thickened part 3.5-4.0 $\mathrm{mm}$ long, slender. Lateral sepals 6.4-6.6 mm long, 4.5-5.0 mm wide, obovate, with slender thickened tails ca $8 \mathrm{~mm}$ long, connate for ca 3.5-3.7 mm. Petals $3.9-4.0 \mathrm{~mm}$ long, ca $1 \mathrm{~mm}$ wide, 1-veined, oblong, narrowed above the middle, apex rounded, subfalcate. Lip 3.8-4.0 $\mathrm{mm}$ long, 3.5-3.8 mm wide, cuneatetriangular, apiculate, apicule small, rounded, disc 3-veined, minutely ciliate in apical part; basal callus pyramidal. Gynostemium stout, ca $3 \mathrm{~mm}$ long, column-foot ca $3 \mathrm{~mm}$ long.

Etymology. Named to honor Ramiro Medina, an orchid enthusiast who cultivated the type specimen.

HABITAT AND DISTRIBUTION. Known only from the type locality where it grows in disturbed humid montane forest at $c a 2300 \mathrm{~m}$ a.s.1.

NotEs. This species is unique in the genus by having a single-flowered inflorescence. No additional floral bracts or flower buds were seen on any of the peduncles. Porroglossum medinae is similar to Peruvian $P$. meridionale and P. peruvianum from which it differs by its short-petiolate leaf, oblong petals narrowed above the middle to a rounded apex, minutely ciliate in the apical part, cuneate-triangular lip with 3-veined disc, and pyramidal basal callus. From $P$. meridionale it is also easily distinguished by the different flower color (light purple with yellow tails and purple lip in $P$. meridionale). The new species resembles Ecuadorian $P$. andreettae Luer, from which it differs by its larger flowers as well as by the shape of the lip and petals.

\section{KEY TO THE COLOMBIAN SPECIES OF} PORROGLOSSUM (after Luer 1987, modified)

1. Rhizome long-repent .... P. eduardi (Rolfe) Sweet 1 . Rhizome caespitose or shortly repent $\ldots \ldots \ldots 2$

2. Inflorescence a single flower ............ P. medinae Kolan. \& Szlach. 

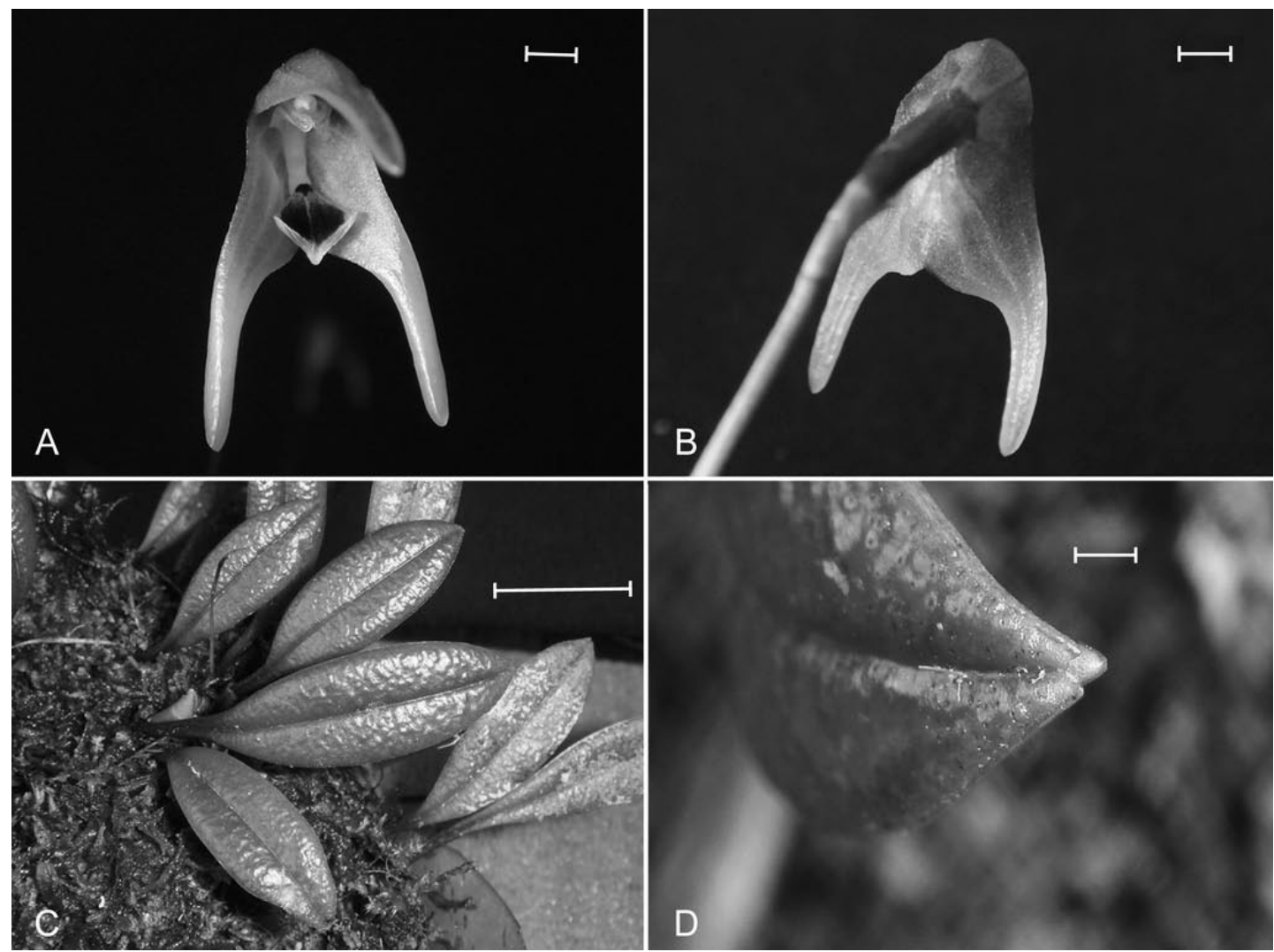

Fig. 2. Porroglossum medinae Kolan. \& Szlach., sp. nov. A - flower (front view), B - flower (back view), C - leaves; D - leaf apex. Photos by R. Medina. Scale bars: A, B \& D = $1 \mathrm{~mm} ; \mathrm{C}=10 \mathrm{~mm}$.

2. Inflorescence a few-flowered raceme ..... 3

3. Peduncle pubescent $\ldots \ldots \ldots \ldots \ldots \ldots \ldots 4$

3. Peduncle glabrous . . . . . . . . . . . . . 6

4. Apex of the synsepal acute... P. parsonsii Luer

4. Apex of the synsepal indented . . . . . . . . 5

5. Tails of the sepals clavate-thickened ........... $\ldots \ldots \ldots \ldots$. . echidna (Rchb. f.) Garay

5. Tails of the sepals slender ...............

............ muscosum (Rchb. f.) Schltr.

6. Dorsal sepal verrucose, not contracted into a tail P. $\boldsymbol{m o r d a x}$ (Rchb. f.) Sweet

6. Dorsal sepal not verrucose, contracted into a tail

............................ 7

7. Tail of the dorsal sepal slender, shorter than the blade ........................ . 8

7. Tail of the dorsal sepal slender or stout, subequal or longer than the blade $\ldots \ldots \ldots \ldots \ldots \ldots 10$ 8. Leaves reticulated ........ P. rodrigoi Sweet
8. Leaves not reticulated ............. 9

9. Tails of the lateral sepals thickened .......... ............ P. nutibara Luer \& Escobar 9. Tails of the lateral sepals slender . . . . . . . . . . ................. P. olivaceum Sweet 10. Dorsal sepal ovate ....... P. sergioi P. Ortiz 10 . Dorsal sepal transversely oblong-ovate ..... P. actrix Luer \& R. Escobar

ACKNOWLEDGEMENTS. We are grateful to Ramiro Medina for providing photos and information about the habitat of the new species, and to Sławomir Nowak for preparing the illustration. We thank the anonymous reviewers for helpful remarks on the manuscript. The research described here was supported by the Polish Ministry of Science and Higher Education (research grant no. 8124/B/PO1/2011/40). 


\section{REFERENCES}

BEAN W. 1887. A sensitive Masdevallia. Gardeners' Chronicle 1: 836 .

Luer C. A. 1987. Systematics of the genus Porroglossum. Monogr. Syst. Bot. Missouri Bot. Gard. 24: 25-90.

LUER C. A. 2002. A systematic method of classification of the Pleurothallidinae versus a strictly phylogenetic method. Selbyana 23(1): 57-110.

LUER C. A. 2011. Miscellaneous new species in the Pleurothallidinae excluding species from Brasil. Harvard Pap. Bot. 16: $311-360$.

Merino G., Doucette A. \& Pupulin F. 2010. New species of Porroglossum (Orchidaceae: Pleurothallidinae) from Ecuador. Lankesteriana 9(3): 459-466.

OLIVER F. W. 1888. On the sensitive labellum of Masdevallia muscosa, Rchb. f. Ann. Bot. 3-4(1888): 237-253.
Ortiz VAldivieso P. \& Uribe VéLez C. 2007. Galería de orquídeas de Colombia (CD edition). Asociación Bogotana de Orquideología, Bogotá.

Pridgeon A. 2005. Porroglossum. In: A. M. Pridgeon, P. J. CribB, M. W. ChASE \& F. N. RASMUSSEN (eds), Genera Orchidacearum, Volume 4. Epidendroideae (part one), pp. 392-395. Oxford University Press, Oxford.

Pridgeon A. M., Solano R. \& Chase M. W. 2001. Phylogenetic relationships in Pleurothallidinae (Orchidaceae): combined evidence from nuclear and plastid DNA sequences. Amer. J. Bot. 88: 2286-2308.

SCHLECHTER R. 1920. Die Orchideenfloren der südamerikanischen Kordillerenstaaten, II. Colombia (II. Beschreibungen neuer Arten). Repert. Spec. Nov. Regni Veg. Beih. 7: 37-161. 